Veronika Rot Gabrovec

University of Ljubljana

Slovenia
2015, Vol. 12 (2), 225-238(244) revije.ff.uni-lj.si/elope

doi: $10.4312 /$ elope.12.2.225-238

UDC: 81 '255.4:821.111-93=163.6

\title{
Translators: Travellers, Not Tourists
}

\begin{abstract}
The article explores various representations of culture(s) found in contemporary English children's literature and discusses how they were rendered into Slovene. In the first part, some introductory definitions of culture and approaches to the translation of children's literature are presented. In the second part, excerpts from selected literary works (for instance, Mary Poppins, Harry Potter and the Philosopher's Stone, Matilda, The Curious Incident of the Dog in the NightTime) are examined, both from the source and the target texts, with more attention paid to the cultural contexts, and the social changes that possibly influenced the translator's decisions.
\end{abstract}

Keywords: children's literature; culture; society; translation

\section{Prevajalci: Popotniki in ne turisti}

\section{POVZETEK}

Članek obrača pozornost na različne reprezentacije kulture, ki jih najdemo v sodobni angleški otroški književnosti, in na načine, kako jih prevajalci prenašajo $\mathrm{v}$ slovenščino. $\mathrm{V}$ prvem delu članka so predstavljene nekatere definicije kulture in pristopi k prevajanju otroške književnosti. $V$ drugem delu je na podlagi obravnavanih odlomkov iz izbranih literarnih besedil (med drugim iz izvirnikov in prevodov knjig Mary Poppins, Harry Potter. Kamen modrosti, Matilda in Skrivnostni primer ali kdo je umoril psa) prikazano, kako tudi kulturni kontekst ter različne spremembe $\mathrm{v}$ družbi lahko vplivajo na prevajalčeve odločitve.

Ključne besede: otroška književnost; kultura; družba; prevod 


\section{Translators: Travellers, Not Tourists}

\section{Introduction}

In times when interdisciplinary approaches are more than merely welcome, I propose a metaphor to start this article: why not perceive the texts we encounter as cultural landscapes? They may come forward as terra firma, with salient natural traits, and all kinds of obvious, easy-to-explain imprints of human activity. On the other hand, the relief of the terrains we approach may but initially seem pleasant; only later do we realise that the growth somewhat resembles entangled thorn bushes, similar to the ones protecting Sleeping Beauty. Alternatively, the intangible textual landmarks may even be difficult to pinpoint and often onerous to translate into another language.

Literary texts have always been a particularly difficult terrain to control - because of its fictionality, a literary work is (usually quite intentionally) more ambiguous than a non-literary one (Eagleton 2014, 120-22). And yet the translators of these texts, and of children's literature in particular, have often been expected to impose a lot of control upon the presumably ideologically questionable culture that could be detected in the bustling landscapes of fiction. Ever since the 1930s, when the first studies appeared as part of comparative literary studies (Bassnett 1993), the translation of children's literature has been investigated through the lenses of ideologies and political control, with particular attention being paid to the relationships between adult authors (writers and translators) and their young readership, and to what is the focus of this article: cultural context adaptations (Lathey 2006).

\section{Culture}

Culture is a complex term that has in the last sixty or seventy years generated a plethora of definitions. In the 1950s Kroeber and Kluckhohn compiled 164 such definitions (cited in Spencer-Oatey 2012). One of the most prolific authors on the (inter)cultural matters of the 1990s, Michael Byram, created the "Model of Intercultural Communicative Competence" (1994, 1998), and more or less equated culture with national culture. The concept was widely accepted in Europe, particularly in education; however, it was also critically viewed by some experts. Kramsch (1999) argued that the culture of a nation is much more heterogeneous than Byram's model might suggest, and Matsuo $(2012$, 375) claimed that such objectification of cultures usually results in monologic discourse - that is, the very concept and indeed the discourse about intercultural communicative competences indicate "a very Western way of thinking whose transferability to cultural contexts that are geographically and culturally distant and/or different is, at the very least, problematic."

For the purposes of this article, we define culture as "the shared patterns of behaviors and interactions, cognitive constructs, and affective understanding that are learned through a process of socialization" (CARLA - Center for Advanced Research on Language Acquisition 2014). These are the patterns that have been constructed as a way of comprehending the world and are reflected in almost every instance of language use (Fowler 1981, 21-27; Ronowicz 1999). It is this "actual, grounded terrain of practices, representations, languages and customs" (Hall in Morley and Chen 1996, 439) that translators walk, with a careful step, and it is here that they enter the world of children and their carnival, all the way learning from them rather than teaching them (Oittinen 2006, 89) - or, alternatively, systematically manipulating the texts, judging, and reshaping them (cf. Biały 2014; Kocijančič Pokorn 2012a, 2012b; Lathey 2010). 


\section{Approaches to Translation: How They Have Changed (or Perhaps Not Changed)}

Literature (be it adapted or specifically written for children) has often been used as a medium through which one can mould the breed. However, the concept of the eighteenth century child "whose natural instincts are not to be trusted" and who is "in constant danger of moral failure, disobedience, or succumbing to prejudice" (Lathey 2010, 77) has been changed, and the child, with their interests, imagery, assumptions and values, is widely accepted as the target audience by authors and translators.

With children's literature gaining value, academics have shown increasing interest in the work of translators of children's literature, those invisible mediators whose language use has always been essential in forming thought, and in (re-)constructing the cultural context (Lathey 2010, 174-75). At the same time, translators are faced with a new challenge: crossover literature. More children's books than ever before address a dual audience of children and adults, and thus the translator has to address both audiences in the target language (Metcalf 2003, 323).

The expanding audience doesn't change the fact that contemporary children's literature - in either the source language or translated into the target language - regularly reproduces ideological effects. The "dialogic, carnivalistic, collaborative process," as Oittinen (2006, 84), in agreement with Bakhtin, calls translation for children, is often a manifestation of power. The relations between cultures have long been asymmetrical, and any transfer process between them is a manifestation of power, be it economic, political or social (Wolf 2002, 187). That said, in both originals and translations, values are still identified in texts and the world still gets interpreted - the 'cultural iceberg' (Brembeck 1977) has always been reminiscent of ideological constructs.

An interesting example is Mary Poppins (Travers 1934), a 'western' children's book that was successfully brought to children 'behind the iron curtain' - albeit with some adaptations. Biały (2014) reports that in socialist Poland of the 1950s Mary Poppins was published as Agnieszka. The famous nanny's name (and thus the title of the book) was changed to a typical Polish name, possibly to make the whole story more familiar to the target audience, and also more acceptable for the socialist readership.

In 1970, Mary Poppins was finally translated into Slovenian; the translator domesticized the nanny's address (Cherry Tree Lane became Češnjev drevored) and some names (for instance, Jane, Michael, John were changed to Jana, Mihec, Janez), but decided that the main character should keep her original name, Mary Poppins. Interestingly, the translator also retained the respectful titles that were used in the source text, although tovaris (comrade) was a widely used address in former Yugoslavia: gospod Banks, gospa Kori, gospodična Slavčeva are more or less equivalent to Mr Banks, Mrs Corry, Miss Lark (that Miss Lark became Miss Nightingale in Slovenian is of no importance here).

In other aspects, however, the Slovenian translator took into consideration the experiences and expectations of the Slovenian young readership of the 1970s. For instance, at the very beginning of Chapter One, the reader is directed to Number Seventeen, Cherry Tree Lane by a bobby (as one would expect in London) in the source text, and by a socialist milicnik in the Slovenian translation (nowadays it would probably be a policist). A detail which does not disturb the reader but is nevertheless interesting is the fact that the Slovenian milicnik kept a British bobby's helmet (Travers 1970, 7), even though the Slovenian police wore caps in the 1970s. 
It seems that in the contemporary socialist Slovenia (Slovenia was then still a part of Yugoslavia), segments of capitalist culture that were shown in children's literature were already seen as much less dangerous than after the Second World War. At a time when religious references were still being erased from children's books, and whole passages adapted or rewritten (Kocijančič Pokorn 2012a, 2012b), a book about a family with five children, live-in servants and a stay-at-home mother (who didn't seem to have much to do, what with a gardener, a cook, a maid and a nanny) was appropriate for Slovenian children of the 1970s. These young readers seem to have been altogether tougher than today's generations anyway: when Mary and Bert the Match Man enjoy their Day Out (Chapter 2), and are pampered in the picture, Bert repeatedly shows his surprise and appreciation by exclaiming 'Golly!' The rather mild exclamation that expresses surprise and wonder was translated as 'Preklemano!' (Travers 1970, 18). The translator possibly felt that this was an exclamation that was robust enough (it is close to 'prekleto', i.e. 'damn'), and at the same time still manageable for the young reader.

But 'ideological hurdles' are cleared or crashed into in other cultures and other countries, too, not just in (former) socialist contexts. As Metcalf (2003, 324) reports, Christine Nöstlinger's novel Konrad oder das Kind aus der Konservenbüchse (1975) was published both in Britain and in the States, with Nöstlinger's "anti-authoritarian and feminist message toned down somewhat in the British and toned down considerably in the American version of the novel". The text was shortened, the focus laid on action. The americanization of the text was further supported by domesticated American illustrations that accompanied the US edition, the children depicted in "an all-American setting". The question remains whether such an approach was simply the result of the prevailing screening process for the imported children's literature in the United States of the 1970s and 1980s (Metcalf 2003, 324), or whether it possibly shows a genuine fear of exposing the children to anything that was (too) foreign and/or unknown.

A similar approach is described by Joosen (2010). The Amazing Love Story of Mr Morf, written in Flemish and illustrated by Carll Cneut (2002), was published in Britain and translated into English by the author himself. Mr Morf, originally a Flemish dog, who is looking for true love and who eventually discovers a partner for life in a flea, is in English looking for a friend. It was not just the "physical impossibility" of a love relationship between a dog and a flea; the English publisher explained to the author that the mention of love itself was the problem (Joosen 2010, 108). With the disturbing elements removed and some dialogues rewritten, the adapted book seemed safer and more appropriate for its new surroundings.

Another, somewhat different but equally interesting example of a changed (visual) text has been spotted in Erika's Story, written by the American author Ruth Vander Zee. My own copy of the picture book about a (Jewish) baby who was thrown from a train (that was most likely taking her family to a concentration camp) had a yellow Magen David on the front cover (Vander Zee 2003), whereas the covers of the editions I saw on the author's website (http://www.ruthvanderzee.com/ erikas-story/) had a five point star.

In an e-mail message to the author, I asked for some explanation, and Ruth Vander Zee correctly assumed that I was probably using the UK edition of the book. She explained that

all of the foreign editions use the Star of David with the exception of the Netherlands. Most of the Asian versions have no star. So you can see there are differences of opinions and somewhat of a social statement by the choice of the star. 
The American version has the five point star because it was the opinion of the editor that Erika's Story is a Holocaust story but, in many ways, a much larger story of hope. And so they chose to intersperse the story with the Star of David but as a final statement, the five point star. Of course this has been criticized but the company held firm to their intention of the book. (November 22, 2009)

Stressing that she can understand both sides well, Vander Zee finished her letter by saying that

[ $\mathrm{t}$ ] here are many nuances in this short story and I guess the simple answer is that the American editor felt it was a story of hope - a Holocaust story but more than that, whereas the foreign editions see it as primarily as a Holocaust story. (November 22, 2009)

When discussing this picture book with students, and talking about the publishers' choices and decisions, I usually come across a range of opinions about its cover page. Some students inevitably feel that the story is a Second World War story, a story about the Holocaust, about survival - and with that also a story of hope for whoever reads it, even if it has the Star of David on the front cover. The yellow star, once worn by Jews and serving as a method of identifying them during the Second World War, thus becomes a symbol of hope for everyone.

While some other students agree with the American publisher, and feel that a yellow five point star is more inclusive and thus more appropriate for this story to be told globally, there have been a few in recent years who immediately rejected the five point star. It seems that in Slovenia, such a star triggers associations with the red star that used to adorn the coats of arms and flags of many socialist and communist countries, former Yugoslavia included. As proven in numerous discussions with my students (2009-2014), the shape (five points) seems in this case to be even more important than the colour (the partisan/communist star was red).

\section{Adaptations: Pottering About}

Just before the dawn of the new millennium, some of the long established British authors were translated and published in Slovenian for the first time (for instance, the first Slovenian translation of one of Enid Blyton's Famous Five books came out in 1988, the first Slovenian translation of one of Jacqueline Wilson's novels in 1999). At the same time, some newly discovered writers achieved fame in Britain, in Slovenia and globally. The 1990s were definitely marked by the appearance of Harry Potter, the story of a boy who perpetually migrated between the world of Muggles and the world of wizards. In 1999, Harry Potter successfully moved to Slovenia, too, quite possibly also because of the translator's relative indifference to the cultural background of Rowlings' text: the translator quite often omitted linguistic material, together with stylistic and cultural references. Thinking of Hall's approach to culture (Barker 2002, 17) as both a series of adaptations to one's physical circumstances and the creation of a new human environment, we understand that Jakob Kenda, the Slovenian translator of the complete Harry Potter series, often departed from the (British-like) culture of the source text and created a very new environment that is rather dissimilar also to the cultural environment of the target reader.

English

$\mathrm{Mr}$ and Mrs Dursley, of number four, Privet Drive, were proud to say that they were perfectly normal, thank you very much. They were the last people you'd expect to be involved in anything strange or mysterious, because they just didn't hold with such nonsense. (Harry Potter and the Philosopher's Stone) 
Slovenian

Gospod in gospa Dursley z Rožmarinove štiri sta bila nadvse ponosna, da sta popolnoma običajni človeški bitji. $S$ čim nenavadnim in skrivnostnim in s podobnimi neumnostmi nikakor nista hotela imeti opravka. (Harry Potter. Kamen modrosti)

(Mr and Mrs Dursley, of number four, Rosemary Drive, were very proud to be perfectly common human beings. They definitely didn't want to get involved in anything strange or mysterious, or any similar nonsense. (Harry Potter. The Stone of Wisdom))

The reader notices straight away the change of the title of the book (a translation move which is not uncommon at all, we should add). In the Slovenian translation, there is no relationship between Potter and the stone implied: this is the first book of the series, and the character's name already stands there like a brand mark.

In the very first paragraph of the novel, the possible shift in point of view (thank you very much) is omitted in Slovenian, and the implications of offence in case of any doubt (important for the character portrayal) are thus lost.

The Slovenian reader does not associate the address (the setting) with anything of any cultural importance - rosemary (rožmarin) possibly reminds one of the area close to the sea. It is not associated with any typical neighbourhoods nor with a particular social class as privet is (Lathey 2003). Nevertheless, rosemary is a plant whose name is much more commonly known in Slovenia than that of the privet (liguster) - which may have been the reason for the translator's choice.

For some reason, the translator has also decided to make the Dursleys 'perfectly normal human beings', as if wanting to stress in a subtle way that the text is soon to introduce other (less common?) types of beings. The English text does not do the same.

Nevertheless, the series of the seven fantasy novels ignited a proper pottermania in Slovenia, and the translator was universally praised in the press. For his work (not just for the Harry Potter series), the Slovenian section of The International Board on Books for Young People nominated Kenda for inclusion on the IBBY Honour List, an accolade he received in 2004.

\section{Domestication: Matilda Repositioned}

In the 1990s, yet another text of a famous English misfit was published in Slovenian: Roald Dahl's Matilda was translated in 1990, only two years after the publication of its source text. Although repositioning the text in Slovenia, the translator of Matilda seems to have shown more respect to the original text than the translator of Harry Potter (Rot Gabrovec 2013).

Bogdan Gradišnik decided to make the text believably "Slovenian" with some (less obvious) wielding of his pen:

The English Matilda (being "a little late in starting school”) is five and a half when she enters school for the first time (Dahl 1988, 66); the Slovenian Matilda, on the other hand, is six and a half on her first school day (Dahl 1990, 78).

- When the narrator talks about his very own approach to writing truthful end-of-term reports (Dahl 1988, 8), he claims 
"Your son Maximilian," I would write, "is a total wash-out."

In Britain, primary school end-of-term reports are (and were at the time) mainly verbal, i.e. descriptive assessments of a child's achievements. In Slovenia, on the other hand, the reports were still numerical (a list of "grades") at the beginning of the 1990s; therefore the translator decided on a slight change of the verb in Slovenian. He added a prefix, changed the verb (write - add in writing), and thus suitably modified the meaning:

"Vaš sin Maksimilijan,” bi pripisal, “je popolna polomija." (Dahl 1990, 6)

("Your son Maximilian," I would add in writing, "is a total wash-out.")

- Another, in my opinion perhaps somewhat less successful attempt to simply adjust the source culture, is Gradišnik's translation of the (common) slang word Matilda's father uses for TV, namely telly ("What's wrong with the telly, for heaven's sake?”, Dahl 1988, 12). The British informal word becomes tevejček in Slovenian ("Kaj, za božjo voljo, je narobe s tevejčkom?", Dahl 1990, 11). Tevejček, a noun only rarely used in Slovenian, is a diminutive for TV, and it sounds unusual, possibly even ridiculous. Of course, this might have been Gradišnik's intention, namely to make Mr Wormwood sound pompous and frivolous.

The translator of course changed some personal names, too, to make the text more available for the young Slovenian readers.

- Matilda remained Matilda - it is (also) a Slovenian name, and, being slightly unusual and eccentric (one would expect an old lady to bear this name, and not a child), the name befits the precocious character.

- 'Miss Jennifer Honey' has become 'učiteljica Milena Medica' (literally teacher Milena Mead) in Slovenian. Gradišnik decided to use a Christian name that hints at the teacher being mild (Sl. mil $=$ Engl. mild $)$ and alliterates with her surname, which works rather well. Honey is masculine in Slovenian (med), the word could function well as a surname but would also seem short and abrupt. Medica (Mead), on the other hand sounds softer, is feminine in Slovenian - and is an existing surname, too.

- The surname of the headmistress Trunchbull became Volovškar with the bull from the English surname being neutered to an $o x(v o l)$. The image of a large bovine beast remains.

At the very time that Matilda was published, there was a change in addressing primary (and secondary) school teachers in Slovenia. The 1990s tried to reposition the teacher in the society, and introduced new ways of addressing them. Before, the teachers in Slovenia were called tovarišica (although literally meaning comrade, semantically the term was used more or less as a genuine synonym for teacher). Ućitelj/uciteljica ('teacher', $\mathrm{m} / \mathrm{f}$ ) and gospod/gospa ('Mr/Mrs') were both used. The translator used the former ('ućiteljica', i.e. teacher) for both Miss Honey and Miss Trunchbull. GospalMrs is more formal and possibly slightly more dignified than uciteljical teacher, thus less suitable for a brute like Trunchbull. On the other hand, gospa/Mrs usually signifies a married status, which is unsuitable for the young Miss Honey. 'Ućiteljica' seems to have been a good choice at the time.

When talking about Miss Trunchbull, however, the translator decided to use yet another name, namely Volovškarca. He used it as the title of a chapter (originally The Trunchbull, Dahl 1988, 
82), and in the text itself. The Slovenian suffix - $c a$ is often added to a female teacher's surname, changing that surname into a less respectful nickname (albeit one that is not necessarily offensive). It is usually used by students when the teacher in question is not present.

With the choice of such a form of the surname, the translator implied the general attitude to the athletic and ruthless educator:

English

When she marched $-\underline{\text { Miss Trunchbull never walked, she always marched like a storm-trooper }}$ with long strides and arms aswinging - when she marched along a corridor you could actually hear her snorting as she went, and if a group of children happened to be in her path, she ploughed right on through them like a tank, with small people bouncing off her to left and right.... (Dahl 1988, 67)

Slovenian

Ko je korakala - Volovškarca ni nikdar hodila, zmerom je korakala ko kakšen jurišnik, z velikanskimi koraki in s silovito zamahujočimi rokami -, kadar je korakala po hodniku, si lahko celo slišal, kako puha skozi nozdrvi, in če se ji je na poti znašla skupina otrok, je kakor tank zaorala naravnost skoznje, da so človečki odskakovali levo in desno. (Dahl 1990, 80)

(When she marched - the Trunchbull never walked, she always marched like a storm-trooper with giant strides and arms aswinging forcefully - when she marched along a corridor you could actually hear how she snorts through her nostrils, and if a group of children happened to be in her path, she ploughed right on through them like a tank, so that the small people bounced off her to left and right.)

The bovine image of Turnbull is clearly reinforced in Slovenian: the Slovenian word for nostrils (nozdrvi), which the translator added to the text, is usually used for animals and not people, and her movements in Slovenian are more exaggerated and more violent because of the added adjectives and adverbs.

\section{Foreignisation: Aliens Who Remain Alien}

A yet different approach was adopted by the translator of The Curious Incident of the Dog in the Night-Time (2003). Vasja Cerar (2004) decided to keep Christopher's story in Britain and to preserve as much of the taste of the source text as possible. In other words, also in the Slovenian edition Christopher John Francis Boone lives in Randolph Street in Swindon and travels to London. There, Christopher is faced with an overabundance of signs that soon become just a big blur (Haddon 2003, 208-9) and the threatening signs remain unchanged in the Slovenian text (Haddon 2004, 216). Place names are the same (e.g. Eastbourne Terrace), as are the newspaper headlines ("Fergie to stay at Manchester United") and also brand names and stores (Sainsbury's, WH Smith). Yet when Christopher talks about his maths exam, the reader learns he is about to sit a Slovenian secondary school-leaving maths exam (matura iz matematike - pp. 254 and 263) and not his A-level, like his English counterpart (p. 249). As this seems to be the only domestication in the text, we can assume that the translator intended to be as clear as possible about the importance of the exam and the main character's abilities: Christopher, a boy with a disability, is taking the same exam as his peers at average secondary schools. It is otherwise rather obvious that the translator does not feel the material world nowadays needs to be adapted to the 
same extent as was the case before the world changed to a global village, i.e. before the birth of the digital natives and the immediate availability of information on almost anything.

However, the real challenges for the translators of texts like The Curious Incident lie elsewhere. Christopher, the narrator and the main character, is a person with an autism spectrum condition.

- Christopher likes lists and detailed, well organized narratives. The last chapter of "his" book (233) is rather long, but very clear. Christopher describes in detail everything that happened on the day his mother took 'Compassionate Leave'. He starts with his breakfast and adds everything that happened afterwards, using mostly the conjunction 'and'. On pages 245-68 of the English edition, there are more than 130 paragraphs starting with the conjunction and (n.b: the same conjunction is very common also within individual paragraphs). 'Then' appears less than 20 times, with more or less the same occurrence of other conjunctions ('but' being the most common of them, followed by 'so).

In the Slovenian translation, 'then' (potem) is used 30 odd times, 'and' (in) fewer than 5 times, with the rest being various structures. As sentence word order in Slovenian is less rigid than in English, this is reflected in Christopher's narrative, too: the narrative approach, typical of Christopher (listing of events), is far less obvious in Slovenian. However, if Christopher's Slovenian narrative seems at least occasionally refined, his original approach to story-telling can still be detected: it is at least implied by the fragmented text, that is, the unusually high number of paragraphs.

- Christopher doesn't like jokes, and metaphors trouble him, yet he nevertheless tends to discuss each of these rather often. In a way, he is a translator himself, since there are plenty of gaps he encounters in communication with other people, and therefore he has to think about language a lot. Occasionally (only rarely), his language usage is rather unusual - but often only in English, and not in Slovenian. When he discusses the reasons for divorce, he explains that 'one of you has done sex with somebody else' (Haddon 2003, 55). In Slovenian, Christopher uses the expression, to have sex ('ker je eden mogoče seksal s kom drugim', Haddon 2004, 60). The translator probably found a commonly-used jargon expression (seksati) more befitting than a (possibly forcefully created) idiomatic mistake.

The last peek at The Curious Incident will be devoted to minute but important segments of any text: punctuation marks.

In the middle of the night, Christopher leaves the house. His mother comes looking for him.

English:

And then I heard Mother's voice and she was shouting, "Christopher...? Christopher... ?" And she was running down the road, so I came out from between the skip and the Ford Transit van and she ran up to me and said, "Jesus Christ," and she stood in front of me and pointed her finger at my face and said, "If you ever do that again, I swear to God, Christopher, I love you, but... I don't know what I'll do." (Haddon 2003, 248)

Slovenian:

Potem sem zaslišal mamo, klicala je »Christopher, Christopher!« Tekla je po sredi ceste, zato sem stopil iz prostora med kesonom in fordovim kombijem, ona se je ustavila pred mano in 
rekla: »Jezus Kristus!« Z iztegnjenim prstom mi je pokazala naravnost v obraz in rekla: „Če mi to samo še enkrat narediš, Christopher, ti prisežem, čeprav te imam rada ... ampak res ne vem, kaj bom naredila s tabo!« (Haddon 2004, 257)

(Then I heard Mother, she was shouting, "Christopher, Christopher!" She was running in the middle of the road, so I came out from between the skip and the Ford van, she stopped in front of me and said, "Jesus Christ!" She pointed her straight finger directly at my face and said, "If you do that just once more, I swear to you, Christopher, although I love you, ... I really don't know what I'll do to you!")

In English, the exclamation mark is used to end an utterance which expresses strong feelings of any kind, and in emphatic or curt commands. In Slovenian, the exclamation mark ends all kinds of emotional utterances, and it is still frequently used after a salutation in a letter (although the comma is becoming more and more common nowadays). It is also possible to end the utterance with more than just one exclamation mark (to express a rather extreme emotional state), or even to pair the exclamation mark with the question mark.

What do the punctuation marks in the excerpt above tell us about the characters? It seems that when Mother shouts in English she is much more at a loss. The question mark at the end of her call denotes a rising intonation, with the triple-dot (ellipsis) possibly marking a (helpless) pause. Because of the reoccurring exclamation marks (it is placed at the end of all her utterances), the Slovenian Mother seems louder, possibly even a shade aggressive.

It is worth noticing that in the 2000s no censorship is needed to 'protect the young' from various religious expressions. The exclamation 'Jesus Christ' is therefore retained. It can be noticed that Mother doesn't 'swear to God' in Slovenian, but just swears - in this case, we are not faced with any censorship, just with the translator's pragmatic decision to simply use a common Slovenian phrase (Prisežem, da ...) to make Mother sound more natural - particularly as she is also pointing at her son with her finger (her body language is more emphasised in Slovenian than in English).

\section{Importance of Cultural Signifiers: Immigrants and Their Taste in Pies}

Most of the books that have been mentioned so far in this article are about characters that live between (at least) two worlds and/or represent misfits. Harry Potter feels like an outsider when with the Dursleys, just as Matilda feels like an outcast in her family. Christopher struggles all the time to learn the language and other sign systems the world around him uses. The last texts discussed in this article, Alan MacDonald's Troll Trouble series (2007), address the topic of immigrants. (The series has been translated into Slovenian by the author of this article.)

The Troll Trouble series is a collection of four books about a Troll family who move from Norway to a fictional place called Biddlesden. The reason for the move is the infamous encounter of $\mathrm{Mr}$ Troll with a strong billy goat who sent him flying from a bridge into a river. (Slovenian children are not as familiar with the intertextual references, i.e. with the story about the three Billy Goats Gruff, as the British are. However, the author mentions just enough detail to narrow the gap and to ensure that the lack of knowledge is not felt as a shortcoming.)

The publisher wanted to have the text domesticated and to make the Troll family settle in Slovenia, the reason being the age of the target readers: the series is meant for the early fluent 
reader levels. The cultural signifiers of the text were - with few exceptions - rather universal. Whatever happens to the Norwegian troll family in Biddlesden could happen in any similarly uniform town with rows of identical houses, lawns, patios, neat flower borders. According to MacDonald (2008), Biddlesden is a bit similar to Milton Keynes, and therefore, the town got called Zala Gorica in Slovenian. The first word, 'zala', is a slightly archaic adjective that means 'pretty'. The second part, 'gorica', is a common Slovenian place name denoting a small hill (often covered in vineyards). Zala Gorica instantly reminds the Slovenian reader of Nova Gorica, one of the bigger Slovenian towns and one that was planned, designed and built from the scratch after the Second World War, in the 1940s and '50s ('Nova' - 'New'), and thus enables a parallel with Milton Keynes, a town that was planned and created in the 1960s.

The Trolls, as mentioned, originate from Scandinavia and are 'foreigners' both in Biddlesden and in Zala Gorica. That is why there was no particular need to change their names. Their new neighbours, the Priddles (Roger, Jackie, Warren), are stereotypically prim and proper, afraid of the unknown and ready to fight tooth and nail for their home (MacDonald 2007). They are the natives, and they thus received new Slovenian names in the domesticated text: Robert, Jana and Vili. The parents have rather common names, Vili is possibly less common for kids but still not unusual. Their surname, Snobez, is derived from snob, which already hints at their haughty character (MacDonald 2013).

Other names in the series have been adapted, translated or appropriated. The one that is possibly interesting for this article is Nisha, one of Ulrik's schoolmates. She's a minor character, with a name that is of Hindi origin. In Slovenia, there are few Asian immigrants, and Nisha is still a rather unknown name; therefore, Nisha became Lejla. This Turkish/Arabic name is rather wellknown in Slovenia (due to the Muslim immigrants from Bosnia), and carries the same meaning as the Hindi Nisha (both names refer to the night).

A rather unexpected challenge for the translator was posed by the cover page of one of the books in the Troll Trouble series, Goat Pie - mainly because of the cover illustration depicting a giant troll holding a large pie. If the horns sticking out of the pie and the beard hanging from the side hint at the filling hiding under the crust, it is the holly twig on top of the pie that gives away the festive occasion.

Whether sweet or savoury, pies are very popular in Britain (and also in other English-speaking countries). Sweet mincemeat pies are traditionally eaten at Christmas, and a meat pie is a food icon in Australia - one of the former New South Wales premiers, Bob Carr, called it the national dish (Lubyckij 2015).

The well-known dish should, at first sight, present a rather simple task for the translator: a pie can easily be translated as pita in Slovenian. But the Slovenian pita traditionally consists of pastry, laden with fruit filling (and possibly covered with a mesh made of pastry). In Bosnia, meanwhile, pita can be made with phyllo and various fillings (spinach, cabbage, cottage cheese) - that's a dish many Slovenians would most probably call burek (in Bosnia, burek is traditionally filled with meat). Both burek and its meatless variant pita came to Slovenia from Bosnia with migrants, and have been among the most popular fast food options for years (see Mlekuž 2008).

Unfortunately, none of the just-described pita varieties look anything like the dish the troll is holding in his hands on the cover page of the book. Neither does 'potica', a type of cake that is traditionally made, and eaten, at Christmas in Slovenia. After some thought, the translator 
decided to use the word pogača, which is used for various types of bread (similar to focaccia) or pastry in Slovenian. Some varieties of Slovenian 'pogaca' fit the image on the book cover, and some of them are indeed savoury, which suits the filling (Goat Pie - Kozja pogača). The translator has thus somehow managed to run with the goat, and hunt with the trolls - or, as one could say in Slovenian, trol je tako sit, koza pa cela.

\section{Conclusion}

Writing about translations for children and her own experiences in that field, Oittinen (2002) suggests the concept of the 'situation' as the key issue. According to her, 'situation' includes time, place, culture, and also (the translator's) ideology (2002, Chapter 1, n.p.). Moreover, the 'situation' makes translation a complex and complicated process. Texts "can be seen as endless chains of interpretations, transformations that take on a new life according to the person reading them" (Oittinen 2002, Chapter 2, n. p.). Translators, on the other hand, are careful readers who bring in their identity and their - often unique - view of life, their activity being dependent on translation norms which "reflect the ideological framework of the target social and language systems" (Orel Kos 2012, 100). Every social system brings its very own and specific ideological filters (Orel Kos 2012, 106), and every translator enters a personal "dialogic relationship" with the text (Oittinen 2002).

The political, ideological and cultural changes that Slovenia has witnessed in the last twenty-five years, the economic ups and downs, the new social stratification, migrations to and from Slovenia, have left an impact on translations of children's literature in Slovenia, too. Not only have the Slovenian young readers finally received the works of some prolific English authors, we can also notice an interesting range of strategies and approaches that are used when translating texts for children.

One thing is certain: when translating (for children or any other reader), the translator no doubt needs a thorough knowledge of both the source and the target culture to re-create a text that enables the Slovenian readers to enjoy reading, and to gain some (inter- or cross-) cultural knowledge. Or, to round the article up with a metaphor: the TV chef Andrew Zimmern once advised his audiences to avoid being mere tourists, since looking beyond what's right in front of one's nose is "the key to understanding this amazing world we live in". To be a traveller, not a tourist, is what's of importance. In the rich landscapes of the texts, translators are definitely travellers.

\section{References}

Bassnett, Susan. 1993. Comparative Literature: A Critical Introduction. Oxford: Blackwell.

Biały, Paulina. 2014. "Snow White Gets Black Hair and Brown Eyes - On Censorship in the Translation of English Children's Literature into Arabic.” Studia Neofilologiczne X. http://dlibra.bg.ajd.czest.pl:8080/ Content/2106/12.pdf. Accessed February 12, 2015.

Brembeck, Winston. 1977. "The Development and Teaching of a College Course in Intercultural Communication.” In Readings in Intercultural Communication, edited by David S. Hoopes, 14-26. Pittsburgh: SIETAR Publications.

Byram, Michael. 1994. Teaching-and-Learning Language-and-Culture. Clevedon: Multilingual Matters.

-. 1998. Teaching and Assessing Intercultural Communicative Competence. Clevedon: Multilingual Matters.

CARLA - Center for Advanced Research on Language Acquisition. 2014. “What is Culture?” http://www.carla. umn.edu/culture/definitions.html. Accessed February 20, 2015. 
Dahl, Roald. 1988. Matilda. London: Puffin Books.

—. 1990. Matilda. Translated by Bogdan Gradišnik. Ljubljana: Mladinska knjiga.

Eagleton, Terry. 2014. How to Read Literature. New Haven: Yale University Press.

Fowler, Roger. 1981. Literature as Social Discourse. The Practice of Linguistic Criticism. Bloomington: Indiana University Press.

Haddon, Mark. 2003. The Curious Incident of the Dog in the Night-Time. London: Vintage.

—. 2004. Skrivnostni primer ali Kdo je umoril psa. Translated by Vasja Cerar. Ljubljana: Mladinska knjiga.

Joosen, Vanessa. 2010. “True Love or Just Friends? Flemish Picture Books in English Translation.” Children's Literature in Education, An International Quarterly 41 (2): 105-117. doi:10.1007/s10583-010-9103-2.

Kramsch, Claire. 1999. "Thirdness: The Intercultural Stance." In Language, Culture and Identity, edited by Torben Vestergaard, 53-89. Aalborg: Aalborg University Press.

Kocijančič Pokorn, Nike. 2012a. “Skrita ideologija v prevodih otroške literature.” In Ideologije v slovenskem jeziku, literaturi in kulturi: zbornik predavanj / 48. seminar slovenskega jezika, literature in kulture, Ljubljana, 2.-13. 7. 2012, 55-61. Ljubljana: Znanstvena založba Filozofske fakultete. http://www. centerslo.net/files/file/ssjlk/48\%20SSJLK/kocijancic\%20pokorn.pdf.

—. 2012b. "Skrita ideologija v prevodih otroške literature." Lecture, 48. seminar slovenskega jezika, literature in culture: Ideologije v slovenskem jeziku, literature in kulturi, Filozofska fakulteta Univerze v Ljubljani, Ljubljana, September 3. http://videolectures.net/ssjlk2012_kocijancic_pokorn_ideologija/.

Lathey, Gillian. 2003. "Workshop on Translation.” Workshop, CLISS, National Centre for Research in Children's Literature, Roehampton, London, July 2003.

- 2010. The Role of Translators in Children's Literature; Invisible Storytellers. Milton Park: Routledge.

Lathey, Gillian, ed. 2006. The Translation of Children's Literature. A Reader. Clevedon: Multilingual Matters.

Lubyckij, Grant. 2015. “Our Top 10 Most Iconic Australian Foods.” Australian Geographic. January 22, 2015. http://www.australiangeographic.com.au/topics/history-culture/2015/01/10-iconic-australian-foods-andtheir-history. Accessed November 15, 2015.

MacDonald, Alan. 2007. Goat Pie. London: Bloomsbury.

—. 2007. Trolls, Go Home! London: Bloomsbury.

—. 2013. Kozja pogača. Translated by Veronika Rot Gabrovec. Maribor: Hiša knjig KMŠ.

—. 2013. Pojdite domov, troli!'Translated by Veronika Rot Gabrovec. Maribor: Hiša knjig KMŠ.

—. n.d. "Bloomsbury Publishing: Alan MacDonald. Troll Trouble." http://www.bloomsbury.com/author/alanmacdonald. Accessed September 15, 2010.

Matsuo, Catherine. 2012. "A Critique of Michael Byram's Intercultural Communicative Competence Model from the Perspective of Model Type and Conceptualization of Culture." Fukuoka University Review of Literature \& Humanities 44 (2): 347-80. http://www.adm.fukuoka-u.ac.jp/fu844/home2/Ronso/Jinbun/ L44-2/L4402_0347.pdf.

Metcalf, Eva-Maria. 2003. “Exploring Cultural Difference Through Translating Children's Literature.” Meta: journal des traducteurs / Meta: Translators' Journal. Traduction pour les enfants / Translation for Children 48 (1-2): 322-27. doi:10.7202/006978ar.

Mlekuž, Jernej. 2008. Burek.si?! Koncepti/recepti. Ljubljana: Studia humanitatis.

Morley, David, and Kuan-Hsing Chen, eds. 1996. Stuart Hall. Critical Dialogues in Cultural Studies. London: Routledge.

Oittinen, Riitta. 2002 (2000). Translating for Children. New York: Garland Publishing. 
—. 2006. "The Verbal and the Visual: On the Carnivalism and Dialogics of Translating for Children." In The Translation of Children's Literature. A Reader, edited by Gillian Lathey, 84-97. Clevedon: Multilingual Matters.

Orel Kos, Silvana. 2012. "Ideologija: izgubljeno ali pridobljeno s prevodom.” In Ideologije v slovenskem jeziku, literaturi in kulturi: zbornik predavanj / 48. seminar slovenskega jezika, literature in kulture, Ljubljana, 2.13. 7. 2012, 100-106. Ljubljana: Znanstvena založba Filozofske fakultete. http://www.centerslo.net/files/ file/ssjlk/48\%20SSJLK/orel\%20kos.pdf.

Ronowicz, Eddie, and Colin Yallop, eds. 1999. English: One Language, Different Cultures. London: Cassell.

Rot Gabrovec, Veronika. 2012 "Roald Dahl's Matilda and Her 'New Home' in Slovenia." In Other Words 40 (Winter): 82-85.

Rowling, Joanne K. 1997. Harry Potter and the Philosopher's Stone. London: Bloomsbury.

—. 1999. Harry Potter. Kamen modrosti. Translated by Jakob Kenda. Ljubljana: Epta.

Spencer-Oatey, Helen. 2012. "GlobalPAD Open House. What is culture? A Compilation of Quotations. GlobalPAD Core Concepts.” http://go.warwick.ac.uk/globalpadintercultural. Accessed February 20, 2015.

Travers, Pamela Lyndon. 1970. Mary Poppins. Translated by Katarina Puc. Ljubljana: Mladinska knjiga.

—. 1998 (1934). Mary Poppins. Hammersmith London: Collins Modern Classic.

Vander Zee, Ruth, and Roberto Innocenti. 2003. Erika's Story. London: Jonathan Cape.

—. Personal Correspondence with Veronika Rot Gabrovec. E-mail, November 22, 2009.

—. n.d. "Ruth Vander Zee, Author. Books. Erika’s Story." http://www.ruthvanderzee.com/erikas-story/ Accessed April 28, 2015.

Wolf, Michaela. 2002. "Culture as Translation - and Beyond. Ethnographic Models of Representation in Translation Studies." In Crosscultural Transgressions. Research Models in Translation Studies II. Historical and Ideological Issues, edited by Theo Hermans, 180-92. Manchester: St. Jerome Publishing. 